David BOLE

Mateja BREG VALJAVEC

Bojan ERHARTIČ

Drago KLADNIK

Katarina POLAJNAR

Aleš SMREKAR

\title{
Presoja primernosti načrtovanih vrtičkarskih območij v Ljubljani
}

V prispevku je na primeru vrtičkarstva $\mathrm{v}$ Ljubljani predstavljen vidik načrtovanja te samooskrbne dejavnosti pridelovanja vrtnin, ki večinoma stihijsko obstaja v vseh urbanih okoljih našega kulturnega okolja. Z vrtičkarstvom se ukvarja nekaj odstotkov prebivalcev slovenskega glavnega mesta, ki jim ta dejavnost bolj kot ekonomsko nujo pomeni rekreacijo in sprostitev, zadovoljenje potrebe po neposrednem stiku $\mathrm{z}$ naravo in možnost pridelave zdrave hrane. Značilno je, da se $\mathrm{z}$ njo večinoma ukvarjajo starejši ljudje, med katerimi jih je več visokošolsko izobraženih, kot bi bilo pričakovati. Večina jih je $\mathrm{z}$ razmerami za vrtičkarstvo zadovoljna. Mestna oblast je začela načrtno odstranjevati vrtičke na zanje neprimernih lokacijah, kot nadomestilo pa je pripravila predlog vrtičkarskih območij, ki naj bi bila urejena tako, da ne bi kazila okolja, in obenem primerno infrastrukturno opremljena. Primernost načrtova- nih lokacij v osnutku izvedbenega prostorskega načrta Mestne občine Ljubljana smo ovrednotili glede na izpolnjevanje pomembnih izločitvenih meril in meril privlačnosti, ki smo jih določili na podlagi anketnih rezultatov, vključenih $\mathrm{v}$ podporo odločanju s pomočjo orodij GIS. Pri izvedbi bo treba zagotoviti dogovorno odločanje $\mathrm{z}$ vključevanjem zainteresirane javnosti ter vzpostavljanje dialoga med občino in vrtičkarji.

Ključne besede: vrtičkarstvo, prostočasna dejavnost, vrtičkarji, izvedbeni prostorski načrt, Ljubljana 


\section{Uvod}

Narava je $\mathrm{v}$ mestih navzoča $\mathrm{v}$ različnih oblikah mestnega zelenja: mestnih parkih, drevoredih, zgodovinskih vrtovih, zelenicah ter tudi vrtovih in vrtičkih. Zelene površine v mestnem tkivu so okolje za zadovoljevanje človekove potrebe po stiku z naravo. Meščani najbolje sprejemajo območja varne, predvidljive narave, torej urejeno mestno zelenje. Nenehno iščejo nove, še bolj neposredne stike z naravo, ki jih morajo skladno s poudarjanjem strpnosti in razumevanja drugačnosti upoštevati mestni politiki in načrtovalci (Simoneti, 2000).

Vrtičkarstvo je večnamenska dejavnost. Njen primarni namen je pridelovanje vrtnin za potrebe vrtičkarjev in potrebe njihove širše družine. Izvaja se na vrtovih, ki niso sestavni del ohišnic okrog individualnih stanovanjskih objektov in so praviloma od njih prostorsko ločeni. Načeloma gre za najeto zemljišče $\mathrm{z}$ razmeroma skromno obdelovalno površino, ki je praviloma del večjega kompleksa. Dejavnost je samooskrbna, saj pridelki praviloma niso namenjeni prodaji.

Čeprav načeloma velja, da so mesta grajena in v njih ni odvečnih praznih prostorov, vrtičkarske komplekse vselej najdemo na mestih, ki vsaj obdobno niso zanimiva za druge dejavnosti, na primer na opuščenih zemljiščih nekdanje urbane rabe, ob vodotokih, pod daljnovodi, ob cestah in drugih prometnicah ter okrog večstanovanjskih hiš. Največji potencial za razvoj vrtičkarstva pa so velika območja javnih zemljišč, ki jih mestne oblasti kot nezazidljiva varujejo za oblikovanje krajine, širitev mesta in tudi varovanje podzemnih vodnih virov.

V Ljubljani bi lahko zaradi dolgotrajnega nezadostnega nadzora in nezadostne okoljske ozaveščenosti vrtičkarjev sčasoma prišlo do nevarnih in škodljivih posledic vrtičkarstva, še zlasti, ker je ta dejavnost locirana večinoma na okoljsko občutljivih območjih. Nekatera vrtičkarska območja so se začela postopno spreminjati v nelegalno pozidana rekreacijsko-barakarska naselja z nelegalnimi dovoznimi potmi, neurejenimi higienskimi razmerami, nelegalnim odvzemom vode ter nenadzorovanim ravnanjem z nevarnimi odpadki in kopičenjem ostankov zašcitnih sredstev.

Takemu početju se je mestna oblast odločila narediti konec. Lotila se je postopnega odstranjevanja nelegalnih vrtičkov na najvpadljivejšsh in okoljsko najranljivejšsih območjih, ob tem pa si prizadeva zagotoviti zemljišča za bolj organizirane, urejene in nadzorovane oblike vrtičkarstva. Pripravljeni so predlogi z okoli 30 lokacijami vrtičkarskih območij. Ustreznost njihovega izbora, ki smo jo preučili kot del posebne raziskave (Vrščaj idr., 2008), vključno z metodologijo, uporabljeno v ta namen, podrobno obravnavamo v drugem delu prispevka, saj so ustre- zno izbrane lokacije zelo pomembne za nadaljnji razvoj te med Ljubljančani zelo priljubljene dejavnosti.

Še prej v izčrpni obliki predstavljamo glavne značilnosti dosedanjega razvoja ljubljanskega vrtičkarstva in ljubljanskih vrtičkarjev, ki smo jih v omenjeni raziskavi (prav tam) še posebej podrobno raziskali. $\mathrm{V}$ tem času se dejavnost vrtičkarstva pomembno preobraža, čeprav se motivi zanjo $\mathrm{v}$ zadnjih letih zagotovo niso bistveno spreminjali. Zaradi tega tudi naše najnovejše, $\mathrm{z}$ anketiranjem zbrane informacije dobivajo zgodovinski pomen.

Anketni vprašalnik je sestavljalo kar 150 vprašanj s številnimi podvprašanji s teh vsebinskih področij:

- lega in opremljenost vrtička,

- značilnosti vrtičkarskega območja,

- zemljiškolastniške razmere,

- socialnoekonomski kazalniki,

- motivi za opravljanje vrtičkarske dejavnosti,

- odnos vrtičkarja do okolja,

- odnos vrtičkarja do prsti,

- odnos vrtičkarja do podtalnice,

- poznavanje vodovarstvenih območij,

- časovna in količinska raba gnojil,

- časovna in količinska raba zaščitnih sredstev,

- pridelki in

- pripravljenost na spremembo lokacije vrtička.

Območja anketiranja smo izbrali po teh kriterijih:

- lega vrtičkarskega območja glede na vodovarstvena območja,

- lastnosti prsti,

- lokacija potencialnih virov onesnaževanja,

- velikost vrtičkarskega območja in

- enakomerna razporeditev vrtičkarskih območij znotraj obstoječih območij v Mestni občini Ljubljana (v nadaljevanju: MOL).

Anketiranje je potekalo od 11. julija do 30. avgusta 2006. Na 34 obstoječih vrtičkarskih območjih smo izvedli 302 anketi. Prvotno smo za anketiranje določili 33 območij; na vsakem naj bi praviloma izvedli po 9 anket. Terensko delo je pokazalo, da je bilo zaradi nezadostne pripravljenosti potencialnih anketirancev na nekaterih območjih na drugih treba izvesti večje število anket, ob tem pa smo vključili še dve dodatni vrtičkarski območji. Na posameznih območjih smo anketirali od 6 do 9 vrtičkarjev, na enem območju samo enega, na glede na število izvedenih anket, na največjem pa celo 19 anket. Samo na enem prvotno izbranem območju (ob Fajfarjevi ulici na Viču) zaradi nesodelovanja tamkajšnjih vrtičkarjev nismo izvedli nobene ankete. Menimo, da približno petodstotni de- 
lež anketirane populacije vrtičkarjev zadostuje zahtevam reprezentativnega vzorca in omogoča posploševanje ugotovitev, postavljanje splošnih vzorcev ravnanja in oblikovanje splošno veljavnih sklepov.

Omenimo naj še, da imamo kot izvajalci raziskave Vrtickarstvo $v$ Mestni občini Ljubljana kot vir onesnaženosti v tleh, pridelani brani in podzemni vodi (Vrščaj idr., 2008) izjemno srečo, da se preučitve ljubljanskih vrtičkov in vrtičkarjev ponavljajo na vsakih nekaj let, kar nam omogoča tudi primerjalne analize. Ker je ta problematika zanimiva za širšo javnost, z njo pa so povezani tudi raznovrstni vidiki in problemi prostorskega razvoja mesta, ni presenetljivo, da je zanimiva za dokaj širok krog raziskovalcev. Prva temeljita preučitev je bila opravljena sredi osemdesetih let prejšnjega stoletja (Goriup, 1984). Izjemno temeljita je bila raziskava Usmeritve in pogoji za nadaljnji razvoj urtičkarstva v Ljubljani (Simoneti idr., 1997). Preučitve so opravili tudi arhitekti (Vastl, 2000). V prvih letih 21. stoletja se je MOL začela vse bolj zavedati težavnosti obvladovanja vse bolj stihijskega razvoja vrtičkarstva, zato je bila opravljena prva ureditvena študija (Gregorič idr., 2004; Doležal idr., 2005). Povsem nove pa so strokovne podlage za urejanje vrtičkarskih območij (Simoneti idr., 2007), ki so podlaga osnutku izvedbenega prostorskega načrta (Mestna občina Ljubljana, 2008).

\section{Temeljne značilnosti ljubljanskih vrtičkov}

Podrobnejši podatki o razporeditvi in površini ljubljanskih vrtičkov so dostopni le za zadnjih nekaj desetletij (preglednica 1).

Leta 1984, ko je bilo vrtičkarstvo v Ljubljani že v precejšnjem razcvetu, so vrtički na 289 območjih zavzemali natanko dva kvadratna kilometra ozemlja. Stihijsko rastoča vrtičkarska območja so bila razporejena po vsem ravninskem delu Ljubljane. Do leta 1995 se je skupna površina vrtičkov povečala za tretjino in narasla na $2,67 \mathrm{~km}^{2}$, število vrtičkarskih območij pa je z vrednostjo 378 doseglo vrhunec. Do leta 2005 sta površina vrtičkov in število vrtičkarskih območij zaradi spremenjenega, bolj urbanega načina življenja precej nazadovala in dosegla skromnejši vrednosti kot leta 1984. Največje nazadovanje smo zasledili na lokacijah v bolj strnjenem delu mesta ali na njegovem robu, ki so izpostavljene najintenzivnejši zazidavi. Tudi z aktivnim posredovanjem mestne oblasti se je število vrtičkarskih območij do leta 2008 zmanjšalo na 218, površina vrtičkov pa se je skrčila na vsega $1,30 \mathrm{~km}^{2}$ oziroma za tretjino.

Preglednica 1: Spreminjanje površine ljubljanskih vrtičkov in števila vrtičkarskih območij med letoma 1984 in 2008

\begin{tabular}{lcccc}
\hline Leto & 1984 & 1995 & 2005 & 2008 \\
\hline Površina $\left(\mathrm{km}^{2}\right)$ & 2,00 & 2,67 & 1,86 & 1,30 \\
\hline Število območij & 289 & 378 & 249 & 218 \\
\hline
\end{tabular}

Vir: Goriup (1984), Simoneti idr. (1997), Geodetska uprava Republike Slovenije (2005), Vrščaj idr. (2008).
Vrtičkarska območja so različno velika, od le nekaj deset kvadratnih metrov do nekaj deset hektarjev. Za vrtičkarsko dejavnost je značilna najemniška struktura. Le $7 \%$ anketiranih vrtičkarjev je tudi lastnikov zemljišč. Med $93 \%$ najemniki ima zemljo dejansko najeto manj kot polovica vprašanih (43\%), preostali (polovica vseh anketiranih vrtičkarjev) pa uporabljajo tako imenovano »nikogaršnjo zemljo«, za katero seveda ne plačujejo najemnine. Kar tri četrtine vrtičkarjev nima podpisane najemne pogodbe. $91 \%$ jih je izjavilo, da ne želijo najeti dodatnih zemljišč za nadaljnje opravljanje oziroma morebitno širjenje vrtičkarske dejavnosti. Le tretjina bi rada zemljišče tudi odkupila.

Da pri pojavu vrtičkarstva v Ljubljani ne gre le za pridobitniško komponento oziroma pridelavo hrane, potrjuje dejstvo, da je na precejšnjem številu vrtičkov tudi okrasni vrt $(28,5 \%)$ in okrasno travinje $(26,5 \%)$. Presenetljivo veliko vprašanih vrtičkarjev ima na parceli sadovnjak (26\%) in celo vinograd (20\%), bolje rečeno brajdo.

Ugotovili smo (Vrščaj idr., 2008), da je leta 2005 površina povprečnega vrtička v Ljubljani merila $205 \mathrm{~m}^{2}$. Od tega je bila skoraj polovica $\left(101 \mathrm{~m}^{2}\right)$ namenjena pridelavi zelenjave (slika 1). Razmeroma veliko prostora je v povprečju zasedalo dvorišče (dobro četrtino ali $55 \mathrm{~m}^{2}$ ); netlakovanih dvorišč je bilo bistveno več kot tlakovanih. Povprečno $16 \mathrm{~m}^{2}$ ali $8 \%$ površine vrtička je zasedal sadovnjak, medtem ko je bila površina $s$ trto precej manjša $\left(6 \mathrm{~m}^{2}\right.$ oziroma $\left.3 \%\right)$. Okrasno travinje je bilo na povprečnem vrtičku zasajeno na $8 \mathrm{~m}^{2}(4 \%)$, okrasni vrt pa se je razprostiral na $5 \mathrm{~m}^{2}(2,4 \%)$.

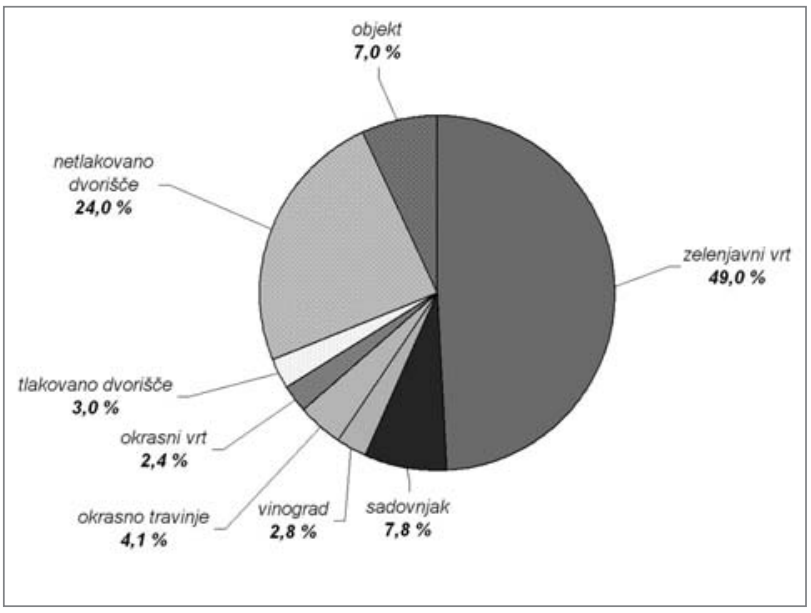

Slika 1: Raba tal na ljubljanskih vrtičkih leta 2005 (vir:Vrščaj idr., 2008)

Infrastrukturna opremljenost vrtičkarskih območij je dokaj slaba. Večina (235) jih je sicer dostopna po dovoznih poteh, vendar te praviloma niso utrjene in so slabo vzdrževane. $\mathrm{Na}$ javni vodovod naj bi bilo priključenih le $15 \%$ vrtičkarskih območij, oskrba z električno energijo pa se pojavlja le izjemoma. 
Skupni objekti so le na peščici vrtičkarskih območij, ob Saveljski cesti v Savljah, Bratislavski cesti v Mostah in Cesti dveh cesarjev na Viču. Nekaj več jih ima urejene skupne sanitarije (12) in skupne zabojnike za odpadke (14). Med območji z urejenimi sanitarijami jih ima pet kemična stranišča, dve pa sta priključeni na javno kanalizacijo, obe v Krakovem, ki je tudi sicer najbolje opremljeno $s$ komunalno infrastrukturo (prav tam).

V nasprotju z vrtičkarskimi območji v Avstriji (ugotovljeno s terenskimi ogledi na območjih Dunaja in Gradca), Nemčiji ali Švici (Christl idr., 2004) ljubljanska vrtičkarska območja praviloma niso ograjena, čeprav so si mnogi vrtičkarji (114 ali $38 \%)$ zamejili in zaščitili »svojo « zemljo z ograjami, največ (38) z zidanimi, redkeje pa z žičnimi (30), živimi mejami (29) in lesenimi plotovi (14).

Dve tretjini vrtičkarjev ima na vrtičku objekt (Vrščaj idr., 2008). Povprečni objekt meri $14 \mathrm{~m}^{2}$ in zaseda okoli $7 \%$ površine vrtička. Objekti so brez načrtov, povsem stihijsko zgrajeni iz najrazličnejših materialov. Spominjajo na zasilne barake, tako da zagotovo ne prispevajo $k$ privlačnejšemu videzu vrtičkarskih območij. V mnogih primerih ne gre le za preproste lope za shranjevanje orodja in pridelkov, ampak za prava počitniška bivališča. Prevladujoč gradbeni material sten je les; lesenih objektov je kar $93 \%$. Med preostalimi jih je največ iz pločevine. Po izsledkih ankete so zidani le štirje objekti, trije so iz opeke, eden pa iz betona. Zaskrbljujoče je dejstvo, da je močno prevladujoča strešna kritina salonit (kar 64 \%). Čeprav so anhovske salonitke z rakotvornim azbestom na večini stanovanjskih in drugih objektov po Sloveniji že zamenjali, smo na ljubljanskih vrtičkih dobili občutek, da lastniki nimajo večjega interesa za zamenjavo nevarne kritine.

\section{Ljubljanski vrtičkarji}

V Ljubljani so se zakupniki manjših zemljiških parcel pojavili na začetku 20. stoletja, ko so na njih obdelovali vrtne gredice in pridelovali vrtnine (Vastl, 2000). Štejemo jih lahko kot začetnike vrtičkarstva. Do konca druge svetovne vojne sta bila za njegov razvoj znaćilna zlasti dva motiva:

- dopolniter nezadostne površine stanovanja z zasebnim odprtim prostorom in

- zagotovitev eksistenčnega minimuma socialno šibkemu sloju s pridelovanjem zelenjave in sadja ter rejo malih živali.

Po drugi svetovni vojni so se motivi za vrtičkarstvo bistveno spremenili. Funkcija preskrbe je usihala, osrednje mesto sta prevzeli funkciji oddiha in rekreacije.
Z vrtičkarstvom se dejavno ukvarja nekaj odstotkov prebivalcev Ljubljane. Natančno število ni znano, pred desetletjem pa je bilo v raziskavi (Simoneti idr., 1997) zelo na grobo ocenjeno, da je bilo v devetdesetih letih prejšnjega stoletja z njim povezanih vsaj 12.000 Ljubljančanov, realnejše se je zdelo število 13.500. Glede na to, da smo že v letu 2005 zaznali precejšnje nazadovanje površine vrtičkarskih območij, lahko z gotovostjo sklepamo, da se je število aktivnih vrtičkarjev zmanjšalo na manj kot 10.000 (Vrščaj idr., 2008).

Zmanjševanje števila vrtičkarjev še ne pomeni, da se potrebe po taki prostočasni dejavnosti bistveno zmanjǔujejo. Gre za dejavnost, ki se $\mathrm{v}$ precejšnji meri prenaša iz roda $\mathrm{v}$ rod. To potrjujejo tudi rezultati raziskave iz osemdesetih let prejšnjega stoletja (Goriup, 1984), ki so razkrili, da kar 88,6 \% vrtičkarjev izhaja iz družin, ki so imele vrt, zato so nanj navezani že od mladosti. Ker je med njimi mnogo priseljencev, to sicer še ne pomeni vrtičkarskih korenin, ampak le dejstvo, da so imeli določen stik z vrtom že v okolju pred preselitvijo v slovensko prestolnico. $\mathrm{V}$ isti raziskavi je bila ugotovljena tudi presenetljiva stalnost in vztrajnost obdelovalcev vrtičkov. Sčasoma je prenehal obdelovati vrtiček le približno vsak šesti vrtičkar, $\mathrm{v}$ glavnem zaradi bolezni ali podobnih razlogov.

V sodobni raziskavi (Vrščaj idr., 2008) smo zajeli 302 nosilca vrtičkarske dejavnosti, vendar je skupni vzorec vključenih, v vrtičkarstvo vpetih oseb 551. Posamezen ljubljanski vrtiček najpogosteje redno obiskujeta po dve osebi $(54,0 \%)$, skoraj natančno tretjina (33,8 \%) pa je vrtičkov, za katere skrbi samo ena oseba. Za slabo desetino (8,3\%) vrtičkov redno skrbijo po tri osebe. V primeru dveh oseb gre običajno za zakonca. Povprečno preživi vrtičkar na svojem vrtičku uro in pol dnevno. Zanimivo je, da je ta čas bistveno krajši od dveh do treh ur, ki jih omenja študija iz osemdesetih let prejšnjega stoletja (Goriup, 1984). Krajšanje časa, preživetega na vrtičkih, je gotovo posledica zaostrenih delovnih razmer, do katerih je prišlo $s$ sodobnimi družbenopolitičnimi spremembami.

Med vrtičkarji je nekaj več žensk kot moških (razmerje 54,1 proti $45,9 \%$ ), kar je gotovo tudi posledica njihove daljše življenjske dobe. Vrtičkarstvo je domena starejših občanov (slika 2). To potrjuje izračun, da je povprečna starost ljubljanskega vrtičkarja 60,6 leta (Vrščaj idr., 2008). Zanimivo je, da je tudi povprečna starost züriškega vrtičkarja 61 let (Christl idr., 2004). Najmlajši ljubljanski vrtičkar je imel med anketiranjem 26 let, najstarejši pa 89.

Izobrazbena sestava vrtičkarjev je slabša od izobrazbene ravni celotnega ljubljanskega prebivalstva (Vrščaj idr., 2008). Razhajanje je zelo očitno v kategoriji višje- in visokošolsko izobraženih (med vsemi Ljubljančani jih je 24,2\%, med vrtičkarji pa le 


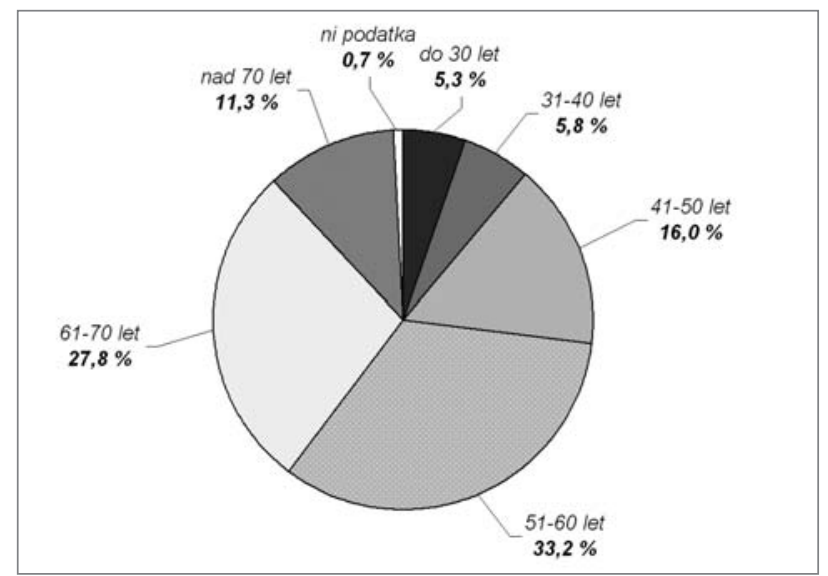

Slika 2: Starostna sestava oseb, ki redno obiskujejo vrtičke (vir: Vrščaj idr., 2008).

$11,8 \%$, kar pa je še vedno več od predvidevanj in pomeni, da je vrtičkarstvo še vedno pomembna vrednota tudi v življenju marsikaterega izobraženca), med preostalimi tremi kategorijami izobraženosti so razlike precej manjše. Deleži prav vseh so med vrtičkarji nekoliko večji. Takšnih, ki imajo končano štiriletno ali petletno srednjo šolo, je 38,1 \% (med Ljubljančani $33,1 \%$ ), s končano dvoletno ali triletno poklicno šolo $23,4 \%$ (med Ljubljančani 21,0 \%) in $s$ končano ali nedokončano osnovno šolo 23,8 \% (med Ljubljančani 21,5\%).

Delež univerzitetno izobraženih ljubljanskih vrtičkarjev se polagoma zmanjšuje, saj jih je bilo pred dobrima desetletjema 12,6 \% (Goriup 1984, 47). Pri interpretaciji tega podatka je potrebna previdnost, saj je treba upoštevati, da se je v tem času izobrazbena raven bistveno dvignila. To pa pomeni, da se med univerzitetno izobraženimi pomen vrtičkarstva, deloma tudi v nasprotju s pričakovanji, ne zmanjšuje, lahko bi celo rekli, da nekoliko pridobiva veljavo.

Dobra polovica ljubljanskih vrtičkarjev je upokojencev (53,4\%), tretjina (32,8\%) pa jih je zaposlena. Delež vseh drugih skupin prebivalstva je bistveno manjš̀i. Razmeroma velik je delež brezposelnih vrtičkarjev (5,6\%), ki pa vendarle ne odstopa ob siceršnjega povprečja brezposelnih Ljubljančanov (Vrščaj idr., 2008).

Nacionalne sestave v najnovejši raziskavi nismo ugotavljali, več kot dvajset let stara študija (Goriup, 1984) pa razkriva, da so bili med vrtičkarji občani, rojeni v drugih republikah in obeh avtonomnih pokrajinah nekdanje Jugoslavije, močneje zastopani kot v celotnem ljubljanskem prebivalstvu. Zunaj Slovenije je bila rojena več kot petina takratnih vrtičkarjev.

Vrtičkarstvo je prostočasna dejavnost mestnega prebivalstva, utesnjenega v blokovskih naseljih in $\mathrm{v}$ vrstnih oziroma individualnih stanovanjskih objektih na izredno majhnih parcelah, ki ne omogočajo ureditve vrtička, tako imenovane ohišnice, ali zelenice neposredno ob objektu. Še zlasti čutijo potrebo po vsaj bežnem »vrtičkarskem « begu v naravo utesnjeni prebivalci stolpnic ali stanovanjskih blokov, postavljenih $\mathrm{v}$ stanovanjskih naseljih z veliko gostoto objektov, ki ljudem razen v stanovanjih ne zagotavljajo skoraj nikakršne zasebnosti (slika 3). Med anketirano populacijo je takšnih skoraj tri petine $(59,3 \%)$ vrtičkarjev. Nadaljnja slaba četrtina (22,8 \%) jih prihaja iz blokov ali stolpnic, ki niso pretirano na gosto postavljeni. 8,6\% vrtičkarjev prebiva v individualnih hišah, $\mathrm{v}$ večstanovanjskih hišah z manj kot petimi stanovanji pa jih živi 7,9 \% (Vrščaj idr., 2008).

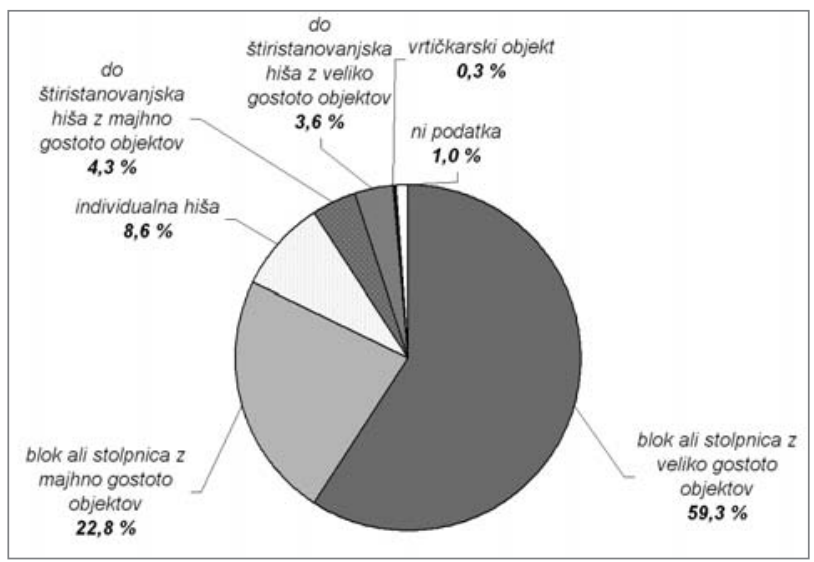

Slika 3: Vrsta bivalne enote, v kateri prebivajo člani vrtičkarskega gospodinjstva (vir: Vrščaj idr., 2008).

Večina vrtičkov je v precejšnji bližini bivališč vrtičkarjev, kar vrtičkarjem omogoča vsakodnevno obiskovanje, še zlasti ob upoštevanju dejstva, da je med njimi veliko upokojencev in tudi precej brezposelnih. Več kot dve petini $(42,1 \%)$ vrtičkov sta od doma svojih uporabnikov oddaljeni manj kot kilometer, nadaljnji dve petini pa sta v razdalji od enega do pet kilometrov, kar je še vedno razmeroma blizu. Nekateri občani so pripravljeni za pot do svojih vrtičkov premagovati tudi precejšnje razdalje, med njimi je dobra dvajsetina (5,3 \%) takšnih, ki obdelujejo več kot $10 \mathrm{~km}$ oddaljene vrtičke (prav tam).

Ker je v tesni povezavi z oddaljenostjo način premagovanja razdalje med domom in vrtičkom, ni presenetljivo, da se vrtičkarji na bližnje vrtičke, ki so oddaljeni največ kilometer, običajno odpravijo kar peš (44,6\%), malo bolj oddaljene poti pa običajno opravijo $s$ kolesom (26,0\%). Slaba šestina (16,2\%) vrtičkarjev se do vrtičkov zapelje z osebnimi avtomobili; takšen dostop je najpogostejši do bolj oddaljenih vrtičkov. Čeprav motorno kolo in motor kot prevozno sredstvo izgubljata pomen, sta zaradi ostarele sestave vrtičkarjev in $s$ tem povezane togosti še vedno omembe vredni prevozni sredstvi (6,8 \%). Le malo manj $(5,7 \%)$ je vrtičkarjev, ki za pot med domom in vrtičkom uporabljajo javni potniški promet, $\mathrm{v}$ našem primeru mestni avtobus (prav tam). 


\section{Motivacijski dejavniki}

Razširjenost vrtičkarstva v mestih lahko razložimo na podlagi spoznanj o razvojni povezanosti človeka z naravo, ki se ohranja v njegovi potrebi po ohranjanju stikov z njo. Ta potreba se zadovoljuje izrazito individualno in je skrajno neoprijemljiva. $\mathrm{Na}$ eni strani se z vrtičkarsko dejavnostjo zadovoljujeta potreba po pristnem in neposrednem stiku »utesnjenih « meščanov $z$ naravo ter želja po rekreaciji in sprostitvi oziroma fizični aktivnosti, na drugi strani pa je razloge za priljubljenost vrtičkarstva treba iskati v eksistenčnih in okoljevarstvenih vidikih pojava (Simoneti idr., 1997). Za mestno prebivalstvo je na splošno značilno občutenje pomanjkanja možnosti vplivanja na svoje življenjsko okolje.

Anketirancem (Vrščaj idr., 2008) vrtičkarska dejavnost v največji meri omogoča rekreacijo in sprostitev (29\% navedb), čemur sledita zadovoljenje potrebe po neposrednem stiku z naravo (22\% navedb) ter zadovoljevanje potrebe po fizični aktivnosti $(20 \%)$. Petini ali $20 \%$ anketirancev pomeni vrtičkarstvo možnost pridelave zdrave hrane. Zanimiva je ugotovitev, da obdelovanje vrtička le še slabi desetini oziroma $9 \%$ anketirancev pomeni možnost pridelovanja hrane zaradi eksistenčnih razlogov. Podoben delež ima tudi motiv preživljanja prostega časa (slika 4).

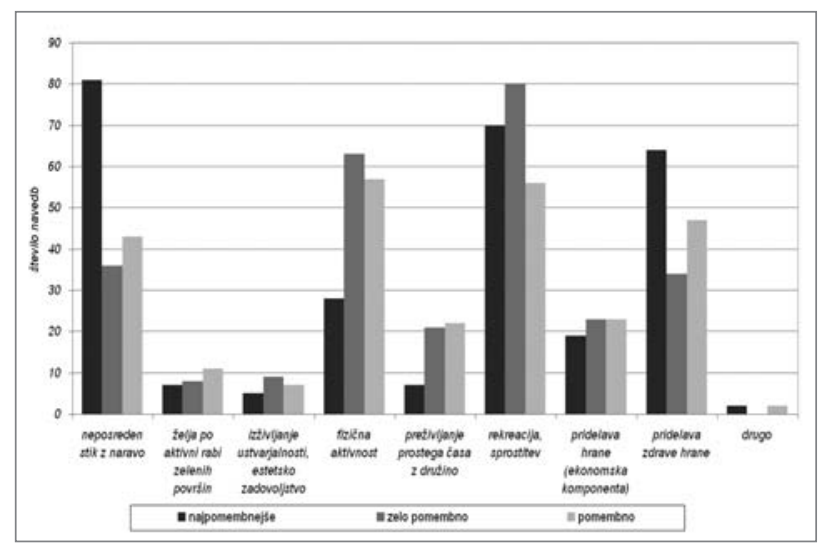

Slika 4: Glavni motivi za ukvarjanje z vrtičkarstvom (vir: Vrščaj idr., 2008)

Zanimivo je, da je bila v letu 2007 (prav tam) kljub takrat začetim ostrim ukrepom proti nelegalnim vrtičkom na posameznih ljubljanskih vrtičkarskih območjih z razmerami za vrtičkarstvo v Ljubljani še vedno zadovoljna precej več kot polovica anketiranih vrtičkarjev. Delež pozitivnih odgovorov je dosegel kar 63,3 \%. 11,6\% vrtičkarjev je bilo celo zelo zadovoljnih, izrazito nezadovoljna pa je bila le slaba desetina $(8,9 \%)$.

Med glavnimi težavami vrtičkarjev so onesnaženi pridelki ob prometnicah in škoda, ki jo na vrtičkih povzročajo sprehajalci. Anketirance motijo tudi kraja pridelkov, škoda, ki jo povzroča divjad, pomanjkanje vode v bližini, hrup z okoliških avtocest, železnic in tovarn, smrad z bližnjih komunalnih odlagališč odpadkov in pomanjkljiva infrastrukturna opremljenost. Nekatere moti tudi neurejen videz. Izpostavljajo še poškodbe na vrtičkarskih objektih, vandalizem, veseljačenje na vrtičkarskih parcelah, pse, ki tacajo po vrtičkih, kopičenje odpadkov, neustrezno uporabo škropiv, neurejeno parkiranje ter težaven dostop zaradi neurejenih dovoznih poti in oddaljenosti vrtičkov od doma, kar se navezuje na gost promet in zamuden dostop in slabšo mobilnost starejših vrtičkarjev. Moti jih tudi značilna slovenska »vrednota «, to je zavist (prav tam).

\section{5 "Vrtičkarska vojna in prizadevanja za načrtno oziroma nadzorovano vrtičkarstvo}

Kljub prizadevanjem za načrtno odpravljanje negativnih vplivov vrtičkarstva je v zadnjih letih še pred celovitim reševanjem prišlo na nekaterih vrtičkarskih območjih do stihijskih posegov mestne oblasti. Kljub pomanjkanju strokovnih mnenj in zastareli zakonodaji (iz srede osemdesetih let) se je aprila 2007 začela »vrtičkarska vojna «, kakor so nekateri mediji poimenovali spor med ljubljanskim županom in vrtičkarji. Gonja proti vrtičkom se je začela na območju ljubljanskih Žal, saj je prevladalo mnenje, da »barakarska naselja « vrtičkarjev ne spadajo v neposredno bližino evropsko pomembne kulturne dediščine, ki jo pomeni Plečnikova arhitektura na Žalah (internet 1). Vzroka za odstranitev ni mogoče iskati le v zanemarjenem videzu nekaterih vrtičkarskih kompleksov, temveč tudi v dejstvu, da so mnogi prebivalci opravljali vrtičkarsko dejavnost na občinski zemlji in zanjo niso plačevali najemnine.

Z odstranjevanjem spornih območij vrtičkov je mestna oblast začela izvajati ukrepe, katerih cilj je zmanjšati sedanjo stihijsko vrtičkarsko dejavnost $\mathrm{z}$ obstoječih $1,30 \mathrm{~km}^{2}$ zemljišč na

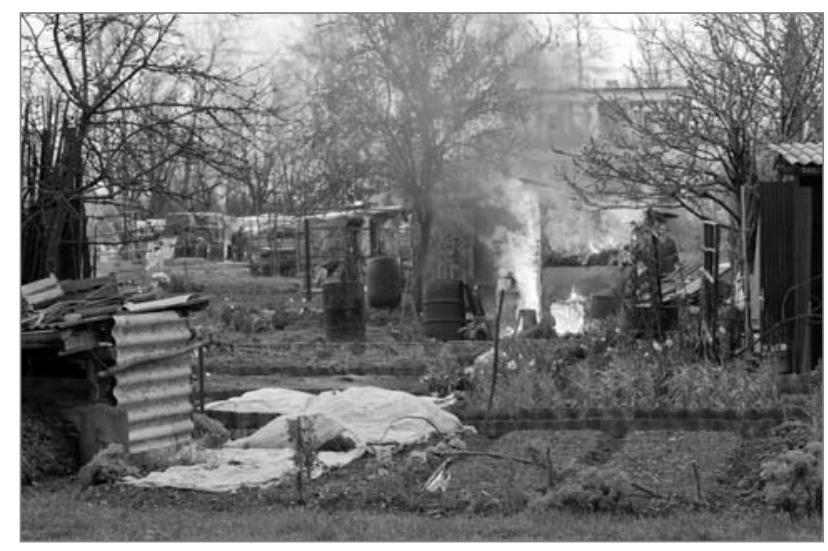

Slika 5: Mnogi vrtičkarji so kot izraz uporništva sežigali svoje objekte pred pokopališčem Žale in za seboj puščali pravo razdejanje (foto: Bojan Erhartič). 
skromnih, vendar z vso potrebno infrastrukturo opremljenih $0,55 \mathrm{~km}^{2}$ načrtovanih vrtičkarskih območij (Mestna občina Ljubljana, 2008). Ob skrbi za urejeno okolje vzdolž mestnih vpadnic v času, v katerem je Slovenija v prvi polovici leta 2008 predsedovala Evropski uniji, je bila dodaten razlog za urejanje in usmerjanje vrtičkarstva zagotovo ugotovitev, da obstajajo na območjih vrtičkov številni vodnjaki in vrtnine, ki so namenjeni zalivanju in namakanju vrtnin na vrtičkih. Samo na območju vrtičkarskega naselja na levem bregu Save, južno od Črnuč, naj bi jih bilo okoli 400 (Smrekar in Kladnik, 2007). Tam so vrtičkarske objekte začeli odstranjevati jeseni 2008.

Vrtičkarje, ki so si na levem bregu Save ustvarili pravo naselbino z ulicami in celo doma narejenimi hišnimi številkami, je mestna oblast pozvala $\mathrm{k}$ prostovoljni odstranitvi objektov, sicer naj bi to na njihove stroške storilo mesto. Hudi krvi in policijski intervenciji je sledilo odstranjevanje objektov, ki pa je bilo tudi zaradi pomanjkanja finančnih sredstev še pred zimo ustavljeno. Sklepamo lahko, da bo MOL v letu 2009 nadaljevala $\mathrm{z}$ odstranjevanjem objektov.

Pred kratkim predlagani Osnutek Odloka o urejanju in oddaji vrtičkov v zakup namenja precejšnjo pozornost varovanju okolja, tako da naj bi bila zalivanju vrtičkov namenjena le deževnica oziroma kapnica (internet 2). Ljubljanski mestni svetniki so ga soglasno potrdili v začetku leta 2009. S tem odlokom naj bi med drugim preprečili, da bi vrtički še vnaprej kazili podobo Ljubljane in preprečili gradnjo pravih vikendskih naselij, kar zagotovo ni temeljni namen vrtičkarstva. Kot je zapisano v omenjenem osnutku odloka, bo občina oddajala mestna zemljišča na začasnih ali trajnih lokacijah, namenjenih spodbujanju vrtičkarstva. Po novem so vrtički opredeljeni kot posebne mestne zelene površine, ki ne bodo nič več locirane na ožjih vodovarstvenih območjih, v mestnem središču in na bolj izpostavljenih lokacijah, ki bi utegnile kaziti podobo ljubljanske pokrajine. Zato vrtičkov po novem ne bo niti v bližini kulturnih spomenikov niti pokopališč.

\section{Presoja načrtovanih lokacij vrtičkov}

V Ljubljani je v najnovejšem osnutku izvedbenega prostorskega načrta (Mestna občina Ljubljana, 2008) predvidenih več kot 30 lokacij vrtičkov, za kar je strokovne podlage, vključno z ureditvenimi pogoji, pripravil Ljubljanski urbanistični zavod (Simoneti idr., 2007). Občinski prostorski načrt, ki naj bi nadomestil vse sedanje prostorske listine, še ni sprejet, osnutek izvedbenega dela prostorskega načrta ( $v$ nadaljevanju: IPN) pa je zelo natančno določil zemljišča za vrtičkarstvo. Opredeljena so v 92. členu osnutka IPN kot »/.../ površine, namenjene

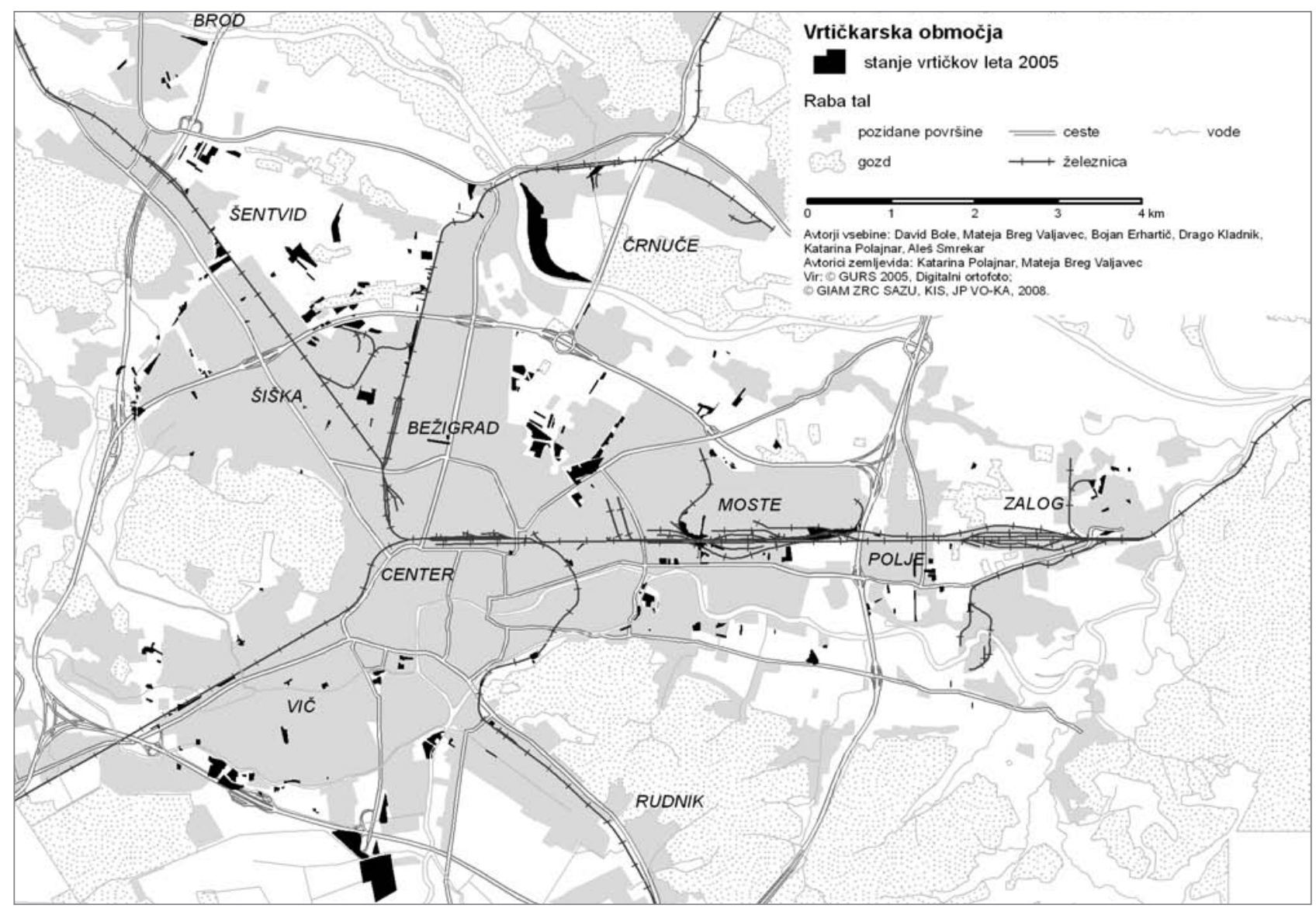

Slika 6: Lokacije vrtičkov leta 2005 in lokacije vrtičkov, predvidene v osnutku IPN MOL (vir: Vrščaj idr., 2008). 
prostočasni dejavnosti pridelovanja vrtnin in gojenja okrasnih rastlin za lastne potrebe« (Mestna občina Ljubljana, 2008). Približno polovica vrtičkov v osnutku IPN je predvidena na že obstoječih vrtičkarskih zemljiščih, druga polovica pa na povsem novih območjih (slika 6).

Presoja primernosti načrtovanih vrtičkarskih zemljiǐ̌c je potekala ob upoštevanju dveh vidikov. Prvi je ovrednotenje predlaganih zemljišč na podlagi strokovne presoje in pričakovanj uporabnikov (vrtičkarjev) ter podajanja končne ocene o njihovi lokacijski primernosti. Ta temelji na kvantitativnem postopku, pri čemer smo upoštevali bistvene kazalnike, ki vplivajo na primernost lokacij vrtičkov. Drugi vidik temelji na analizi lastništva zemljišč, na katerih so predlagana vrtičkarska območja. Izhajamo iz domneve, da prevelika zemljiška in lastniška razdrobljenost otežuje skupno načrtovanje in urejanje teh območij, zato smo s pomočjo digitalnega katastra MOL podrobno preučili lastniško sestavo lokacij predvidenih vrtičkov.

Pri načrtovanju lokacij vrtičkov je zelo pomembno poznavanje dejavnikov, ki vplivajo na primernost njihove lokacije. Lokacije vrtičkov so namreč rezultat številnih dejavnikov, ki se po pomenu razlikujejo; njihovo poznavanje je pri načrtovanju novih lokacij velika prednost. Samo tako lahko zagotovimo, da bodo nove lokacije res zaživele in zadovoljevale potrebe prebivalstva. V nasprotnem primeru se vrtički spet lahko začnejo širiti zunaj načrtovanih območij, na lokacijah, ki so za uporabnike primernejše.

\subsection{Metodološki postopek}

Merila za določanje primernosti vrtičkarskih območij v osnutku IPN MOL smo določali zlasti na podlagi anketnih rezultatov in strokovne ocene. Razdelimo jih lahko na izločitvena merila in merila privlačnosti.

S tako imenovanimi izločitvenimi merili smo preverili, ali med predlaganimi vrtičkarskimi območji obstajajo tudi območja, ki iz zakonodajnih, urbanističnih, zdravstvenih in/ali okoljevarstvenih razlogov niso primerna. Mednja spadajo najranljivejša ožja vodovarstvena območja, območja znotraj zgodovinskega mestnega središča ter območja v neposredni bližini vodotokov, odlagališč odpadkov in večjih prometnic, kar lahko pomembno vpliva na kakovost in s tem varnost pridelane hrane. Izločitveni kazalniki predstavljajo tisti »minimum «, ki bi mu nova območja vrtičkov morala povsem ustrezati, saj so določena na podlagi strokovne ocene in zakonodajnih omejitev.

$S$ tako imenovanimi merili privlačnosti opredeljujemo potencialno privlačnost vrtičkov za uporabnike. So izjemno po- membna, saj morajo razmere na novih vrtičkarskih območjih ustrezati uporabnikom in tudi širši skupnosti. Če so vrtički glede na uporabnike umeščeni na neustreznih lokacijah, se to lahko izrazi v nastajanju novih nelegalnih vrtičkov, ki so za uporabnike (vrtičkarje) ustreznejši. Ta merila smo določali na podlagi anketiranja vrtičkarjev, pri čemer smo posameznih lokacijskim dejavnikov pripisali ustrezno veljavo glede na pomembnost odgovorov v anketnem vprašalniku. Anketiranci so na primer kot bistveni dejavnik za lokacijo vrtička omenjali dostopnost. Kar dve tretjini anketirancev sta odgovorili, da je ta okoliščina najpomembnejša. Za veliko večino anketirancev (82\%) je sprejemljiva razdalja do $5 \mathrm{~km}$, kar se skoraj povsem ujema tudi z obstoječim stanjem anketiranih vrtičkarjev. $83 \%$ jih namreč dejansko prebiva manj kot $5 \mathrm{~km}$ od vrtička. Iz rezultatov ankete je torej mogoče povzeti, da vrtičkarji ne želijo poslabšanja dostopnosti, kar je pri načrtovanju novih lokacij zagotovo treba upoštevati. Med pomembnejšimi dejavniki sta tudi rodovitnost zemljišča in odmaknjenost od prometnic, med manj pomembnimi pa lahko navedemo splošno pokrajinsko mikavnost, kot so bližina gozda, reke, družabnost in tišina. Kazalnike za dostopnost smo torej določili na podlagi navedb $\mathrm{v}$ anketi, upoštevali pa smo tudi dostopnost do postajališč javnega prometa, saj ima javni promet kot edina prava alternativa manj zaželenemu osebnemu prometu v prostorskem načrtu Ljubljane pomembno vlogo. Kot najmanj pomemben dejavnik se je pokazala dostopnost do vodotokov, zato smo njen pomen pri določanju celovite primernosti ustrezno zmanjšali.

Med merili privlačnosti vrtičkov za vrtičkarje so tudi tista, povezana z zdravjem in rodovitnostjo prsti. Po anketnih rezultatih ima največji pomen primernost prsti, nekoliko manjši pa oddaljenost od glavnih onesnaževalcev - prometnic, območij industrijske dejavnosti in drugih intenzivnih dejavnosti. Med slednje smo uvrščali tudi nakupovalna središča, zaradi katerih nastajajo močni prometni tokovi. Pri prometnicah smo upoštevali državne prometnice višje kategorije, torej avtoceste, hitre ceste, regionalne ceste in železnice. Primernost prsti je ocenjena na podlagi vsebnosti organskih snovi, suma onesnaženosti s težkimi kovinami ter globine in teksture.

Zadnjo skupino meril privlačnosti smo poimenovali »vplivi na okolje«. Pomeni najmanjši delež skupne ocene. Njen pomen je določen na podlagi strokovne ocene, $v$ njej pa sta kazalnika, ki vplivata na splošno stanje okolja. Z vidnega zornega kota je pomembno, da je zagotovljena vsaj minimalna oddaljenost vrtičkarskih območij od že pozidanih zemljišč ali zemljišč, predvidenih za pozidavo. Majhen delček v skupni oceni privlačnosti ima tudi lokacija na različnih vodovarstvenih območjih, saj naj tudi na širših vodovarstvenih območjih vrtički ne bi imeli pomembnejšega negativnega vpliva na kakovost podtalnice. 
Preglednica 2: Nabor izločitvenih meril in meril privlačnosti glede na njihov prispevek k skupni oceni privlačnosti

\begin{tabular}{|c|c|c|}
\hline \multicolumn{2}{|r|}{ Ime merila } & \multirow[t]{2}{*}{$\begin{array}{l}\text { Skupni delež k oceni } \\
\text { privlačnosti }\end{array}$} \\
\hline I. & Izločitvena merila & \\
\hline 1. & zunaj mestnega središča & / \\
\hline 2. & zunaj najožjega vodovarstvenega območja (VVO I) & / \\
\hline 3. & zunaj ožjega območja vodotokov (50 m) & / \\
\hline 4. & zunaj ožjega območja gozdov in odlagališč odpadkov (100 m) & l \\
\hline 5. & zunaj ožjega območja prometnic (avtocesta 100 m, regionalna cesta 30 m, železnica 30 m) & I \\
\hline II. & Merila privlačnosti & \\
\hline \multicolumn{2}{|c|}{ 1. dostopnost, opremljenost } & skupaj $50 \%$ \\
\hline \multirow[t]{7}{*}{ A } & oddaljenost od blokovske soseske & $25 \%$ \\
\hline & do $1000 \mathrm{~m}=5$ točk & \\
\hline & od 1000 do $2000 \mathrm{~m}=4$ točke & \\
\hline & od 2000 do $3000 \mathrm{~m}=3$ točke & \\
\hline & od 3000 do 4000 m = 2 točki & \\
\hline & od 4000 do $5000 \mathrm{~m}=1$ točka & \\
\hline & nad $5000 \mathrm{~m}=0$ točk & \\
\hline \multirow[t]{5}{*}{ B } & oddaljenost od postajališča javnega potniškega prometa & $10 \%$ \\
\hline & do $300 \mathrm{~m}=3$ točke & \\
\hline & od 300 do $600 \mathrm{~m}=2$ točki & \\
\hline & od 600 do $1000 \mathrm{~m}=1$ točka & \\
\hline & nad $1000 \mathrm{~m}=0$ točk & \\
\hline \multirow[t]{7}{*}{ C } & komunalna opremljenost - voda, kanalizacija & $10 \%$ \\
\hline & opremljenost z vodovodom in s kanalizacijo = 4 točke & \\
\hline & $\begin{array}{l}\text { opremljenost } z \text { vodovodom ali s kanalizacijo in priključno točko za vodovod ali kanalizacijo } \\
\text { do } 100 \mathrm{~m}=3 \text { točke }\end{array}$ & \\
\hline & $\begin{array}{l}\text { opremljenost z vodovodom ali s kanalizacijo in priključno točko za vodovodom ali kanalizad } \\
\text { sti nad } 100 \mathrm{~m}=2 \text { točki }\end{array}$ & \\
\hline & priključni točki za vodovod ali kanalizacijo v oddaljenosti do $100 \mathrm{~m}=2$ točki & \\
\hline & $\begin{array}{l}\text { priključna točka za vodovod ali kanalizacijo v oddaljenosti do } 100 \mathrm{~m} \text { in za vodovod ali kana } \\
\text { ljenosti nad } 100 \mathrm{~m}=1 \text { točka }\end{array}$ & \\
\hline & priključni točki za vodovod ali kanalizacijo, oboje v oddaljenosti nad $100 \mathrm{~m}=0$ točk & \\
\hline \multirow[t]{4}{*}{ D } & oddaljenost od vodotoka & $5 \%$ \\
\hline & do $100 \mathrm{~m}=2$ točki & \\
\hline & od 100 do $200 \mathrm{~m}=1$ točka & \\
\hline & nad $200 \mathrm{~m}=0$ točk & \\
\hline \multicolumn{2}{|c|}{ 2. zdravje, rodovitnost } & skupaj $45 \%$ \\
\hline \multirow[t]{6}{*}{$\mathrm{A}$} & primernost prsti za vrtičkarstvo & $15 \%$ \\
\hline & zelo primerna prst $=4-5$ točk & \\
\hline & primerna prst $=3-4$ točke & \\
\hline & primerna in manj primerna prst $=2-3$ točke & \\
\hline & manj primerna in neprimerna prst $=1-2$ točki & \\
\hline & oporečna prst = manj kot 1 točka & \\
\hline
\end{tabular}




\begin{tabular}{|c|c|c|}
\hline \multirow[t]{2}{*}{ B } & oddaljenost od prometnice & $15 \%$ \\
\hline & \multicolumn{2}{|l|}{ nad $1000 \mathrm{~m}=3$ točke } \\
\hline & \multicolumn{2}{|l|}{ od 500 do $1000 \mathrm{~m}=2$ točki } \\
\hline & \multicolumn{2}{|l|}{ od 100 do 500 m = 1 točka } \\
\hline & \multicolumn{2}{|l|}{ do $100 \mathrm{~m}=0$ točk } \\
\hline \multirow[t]{5}{*}{ C } & oddaljenost od industrijskega objekta & $10 \%$ \\
\hline & \multicolumn{2}{|l|}{ nad $1000 \mathrm{~m}=3$ točke } \\
\hline & \multicolumn{2}{|l|}{ od 500 do 1000 m = 2 točki } \\
\hline & \multicolumn{2}{|l|}{ od 100 do 500 m = 1 točka } \\
\hline & \multicolumn{2}{|l|}{ do $100 \mathrm{~m}=0$ točk } \\
\hline \multirow[t]{5}{*}{ D } & oddaljenost od drugih intenzivnih dejavnosti (nakupovalno središče, poslovna cona ...) & $5 \%$ \\
\hline & \multicolumn{2}{|l|}{ nad $1000 \mathrm{~m}=3$ točke } \\
\hline & \multicolumn{2}{|l|}{ od 500 do 1000 m = 2 točki } \\
\hline & \multicolumn{2}{|l|}{ od 100 do $500 \mathrm{~m}=1$ točka } \\
\hline & \multicolumn{2}{|l|}{ do $100 \mathrm{~m}=0$ točk } \\
\hline \multicolumn{2}{|c|}{ 3. vplivi na okolje } & skupaj $5 \%$ \\
\hline A & primerna oddaljenost od pozidanega območja (do 200 m) & $2,5 \%$ \\
\hline & \multicolumn{2}{|l|}{ nad 200 m = 2 točki } \\
\hline & \multicolumn{2}{|l|}{ od 100 do $200 \mathrm{~m}$ = 1 točka } \\
\hline & \multicolumn{2}{|l|}{ do $100 \mathrm{~m}=0$ točk } \\
\hline \multirow[t]{5}{*}{ B } & širše vodovarstveno območje (VVO Ila, Ilb, III) & $2,5 \%$ \\
\hline & \multicolumn{2}{|l|}{ zunaj VVO = 3 točke } \\
\hline & \multicolumn{2}{|l|}{ VVO III = 2 točki } \\
\hline & \multicolumn{2}{|l|}{ VVO Ilb = 1 točka } \\
\hline & VVO Ila = 0 točk & \\
\hline
\end{tabular}

Opomba: VVO pomeni vodovarstveno območje.

\subsection{Rezultati presoje primernosti načrtovanih vrtičkarskih območij v osnutku IPN MOL}

Postopek presoje primernosti načrtovanih lokacij vrtičkov je potekal $\mathrm{v}$ dveh fazah. $\mathrm{V}$ prvi smo na podlagi izločitvenih meril presodili, katera v osnutku IPN predlagana vrtičkarska območja so zaradi zdravstvenih, zakonskih in urbanističnih razlogov deloma ali povsem neprimerna. $\mathrm{V}$ drugi fazi smo na podlagi meril privlačnosti presojali še primernost posameznih območij z vidika privlačnosti za uporabnike (vrtičkarje).

Med predvidenimi lokacijami vrtičkov smo najprej preverili, ali ustrezajo izločitvenim merilom. Vseh pet meril v celoti izpolnjujejo lokacije zunaj mestnega središča ter v zadostni oddaljenosti od prometnic, vodotokov, odlagališč odpadkov, gozdov in najožjega vodovarstvenega območja. Primerna oddaljenost od večjih vodotokov (Sava, Ljubljanica, Glinščica, Gradaščica, Mali Graben in Ižica) je delno sporna na dveh lokacijah, kjer več kot $10 \%$ območja vrtičkov sega znotraj $50 \mathrm{~m}$ omejitvenega pasu. Gre za vrtičke v neposredni bližini Save v Šiški (oznaka ŠE-309) in Malega Grabna (TR-122). Kot najpomembnejše izločitveno merilo so se izkazale prometnice, saj kar štiri predvidena območja vrtičkov postavljenim kriterijem ne ustrezajo povsem. Vrtičkarski območji na Viču (RD-73 in RD-116) sta v neposredni bližini železniške proge in mestne vpadnice, območji ob Savi (ŠE-309) in Cesti dveh cesarjev (TR-100) pa preveč blizu avtoceste.

Na karti so označene lokacije vrtičkov, ki niso primerne, ker ne izpolnjujejo v celoti enega merila ali več teh, ali so le deloma primerne, saj postavljena merila samo delno izpolnjujejo ( $90 \%$ površine območja vrtičkov je na primer zunaj omejitvenega območja, $10 \%$ pa znotraj njega). Popolnoma neprimerna so tri vrtičkarska območja, ker ne izpolnjujejo meril ustrezne oddaljenosti od večjih prometnic, deloma primerni pa sta dve območji, ki ne izpolnjujeta v celoti meril o ustrezni oddaljenosti od večjih vodotokov (slika 7).

$\mathrm{V}$ drugi fazi so bila preverjena merila dostopnosti in opremljenosti, zdravja in rodovitnosti ter vplivov na okolje. Gre za merila privlačnosti, ki na podlagi pričakovanj vrtičkarjev in deloma strokovne ocene poskušajo odgovoriti, katera na- 


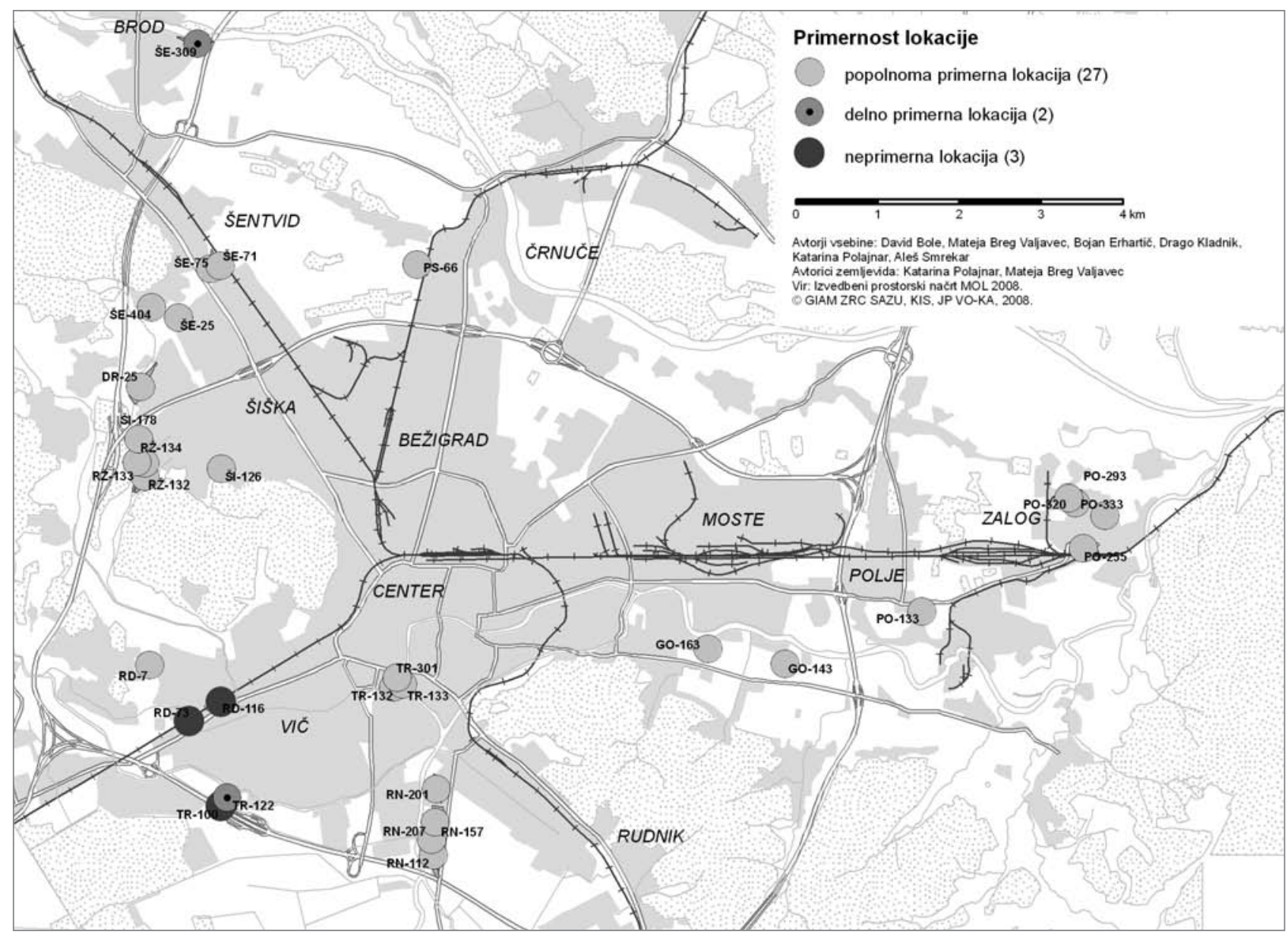

Slika 7: Primernost vrtičkarskih območij, predvidenih v osnutku IPN MOL, glede na izločitvena merila (vir: Vrščaj idr., 2008).

črtovana območja vrtičkov so primernejša in katera so manj primerna. Zlasti za najmanj primerna območja je smiselna ponovna presoja pripravljavcev prostorskega načrta o primernosti teh lokacij.

Ugodna prostorska dostopnost se najpogosteje omenja v povezavi $s$ »privlačnostjo « posameznih vrtičkov. Ker med uporabniki vrtičkov prevladujejo prebivalci večjih stanovanjskih sosesk, smo preverili povprečno oddaljenost blokovskih sosesk od predvidenih območij vrtičkov. Blokovske soseske smo digitalizirali na podlagi predhodne morfološke analize (Rebernik, 2000). Glavna ugotovitev je, da je dostopnost ugodna. Izjeme so območje ŠE-309 na skrajnem severu Ljubljane in povsem na novo načrtovana območja ob Ljubljanici, ki imajo oznako RN. Večina drugih predvidenih vrtičkarskih območij je od večjih blokovskih sosesk oddeljena manj kot kilometer.

Dostopnost do javnega potniškega prometa je nekoliko slabša. Po neugodni povezanosti znova izstopa skrajno severno območje in tudi vrtičkarska območja v Kosezah, ki so nadpovprečno oddaljena od postajališč. Ta območja izstopajo tudi po slabši opremljenosti z osnovno infrastrukturo (vodovod in kanalizacija), kar pomeni, da bi bili za zagotovitev vsaj temeljne komunalne opremljenosti potrebni določeni gradbeni posegi.

Skupna ponderirana ocena primernosti prsti kaže, da imajo najprimernejšo prst vrtičkarska območja na Livadi (oznaka RN), najmanj primerno pa že obstoječi vrtički v Krakovskem predmestju (TR-301, TR-132 in TR-133), kjer je prst za vrtičke manj primerna oziroma sploh ni primerna. Manj primerna je tudi prst na območju Viča (RD-73 in RD-116).

Oddaljenost od prometnic je pomembna z vidika zdravja uporabnikov vrtičkov. Ti večinoma pridelujejo zelenjavo za svoje potrebe ter bližino avtocest in drugih prometnic ocenjujejo kot negativen dejavnik. Večina predvidenih vrtičkarskih območij je ustrezno oddaljena od prometnic, izstopata le območji ob Celovški cesti v Šškki (ŠE-71 in ŠE-75), ki sta v neposredni bližini glavne mestne vpadnice, železnice in avtoceste. Glede na oddaljenost od predvidenih industrijskih dejavnosti je izrazito slabo locirano vrtičkarsko območje PO-320, ki meji neposredno na industrijsko cono v Zalogu.

Pri določanju primernosti imajo najmanjšo vrednost vplivi na okolje, saj vrtički na okolje praviloma ne vplivajo negativno. To lahko zatrdimo tudi za estetski vidik, ob domnevi - da 
bodo ustrezno oblikovani in umeščeni v prostor -, ki naj bi jo načrtovana vrtičkarska območja vsekakor izpolnjevala.

Celotna sintezna ocena na podlagi meril privlačnosti je za načrtovana območja vrtičkov dokaj ugodna, saj vse lokacije dosegajo več kot polovico od skupaj 33 mogočih točk. Kljub temu so opazne določene razlike - najslabšo primernost imajo vrtičkarska območja v Šiški in Polju, zlasti zaradi neugodne bližine večjih prometnic in neprimerne prsti. Skupaj ti merili prispevata več kot tretjino celotne ocene, zato močno prispevata $\mathrm{k}$ nižji oceni vseh treh navedenih vrtičkarskih območij. Med 69 in $75 \%$ mogočih točk imajo zaradi različnih razlogov vrtičkarska območja na Viču, ob Savi in za Bežigradom. Vrtičkarsko območje ob Savi je slabo dostopno in precej oddaljeno od blokovskih sosesk, območje na Viču ima nižjo oceno zaradi bližine prometnic in slabše prsti, območje v Zalogu pa zaradi neposredne bližine industrijske cone v Zalogu.

Med privlačnejša spada predvideno vrtičkarsko območje na Livadi (oznaka RN), ki je dobro oceno doseglo zaradi zelo kakovostne prsti, že obstoječe opremljenosti z vodovodom in $s$ kanalizacijo ter primerne oddaljenosti od nezaželenih dejav- nikov (prometnice, industrijske cone in podobno). Njihova slabost je le nekoliko večja oddaljenost od blokovskih sosesk. Zelo dobro so ocenjena zdaj že zgodovinsko pomembna območja vrtičkov na Krakovem in posamična razpršena vrtičkarska območja, na primer v Štepanjskem naselju in Ššski (slika 8).

\subsection{Lastniška sestava vrtičkarskih območij, predvidenih v osnutku IPN MOL}

Z vidika uspešnega umeščanja vrtičkarskih območij v prostor je zaželena tudi kar najboljša lastniška sestava vključenih parcel. Uresničevanje različnih infrastrukturnih, estetskih in drugih ureditvenih prostorskih pogojev je namreč odvisno tudi od lastništva zemljišč, predvidenih za ureditev vrtičkarskih območij. Zaželeno je namreč, da je lastniška sestava čim enotnejša. Posebno ugodna je, če je večinska lastnica MOL, saj je možnost enotne ureditve, enotnega upravljanja in priključitve na ustrezno infrastrukturo večja, kot če je vrtičkarsko območje razdeljeno med množico drobnih zasebnih zemljiških lastnikov. Vrtičke naj bi namreč MOL oddajala v zakup in od zakupnikov za dobo od enega do petih let zahtevala plačilo za obratovalne in vzdrževalne stroške (Petkovšek, 2009).

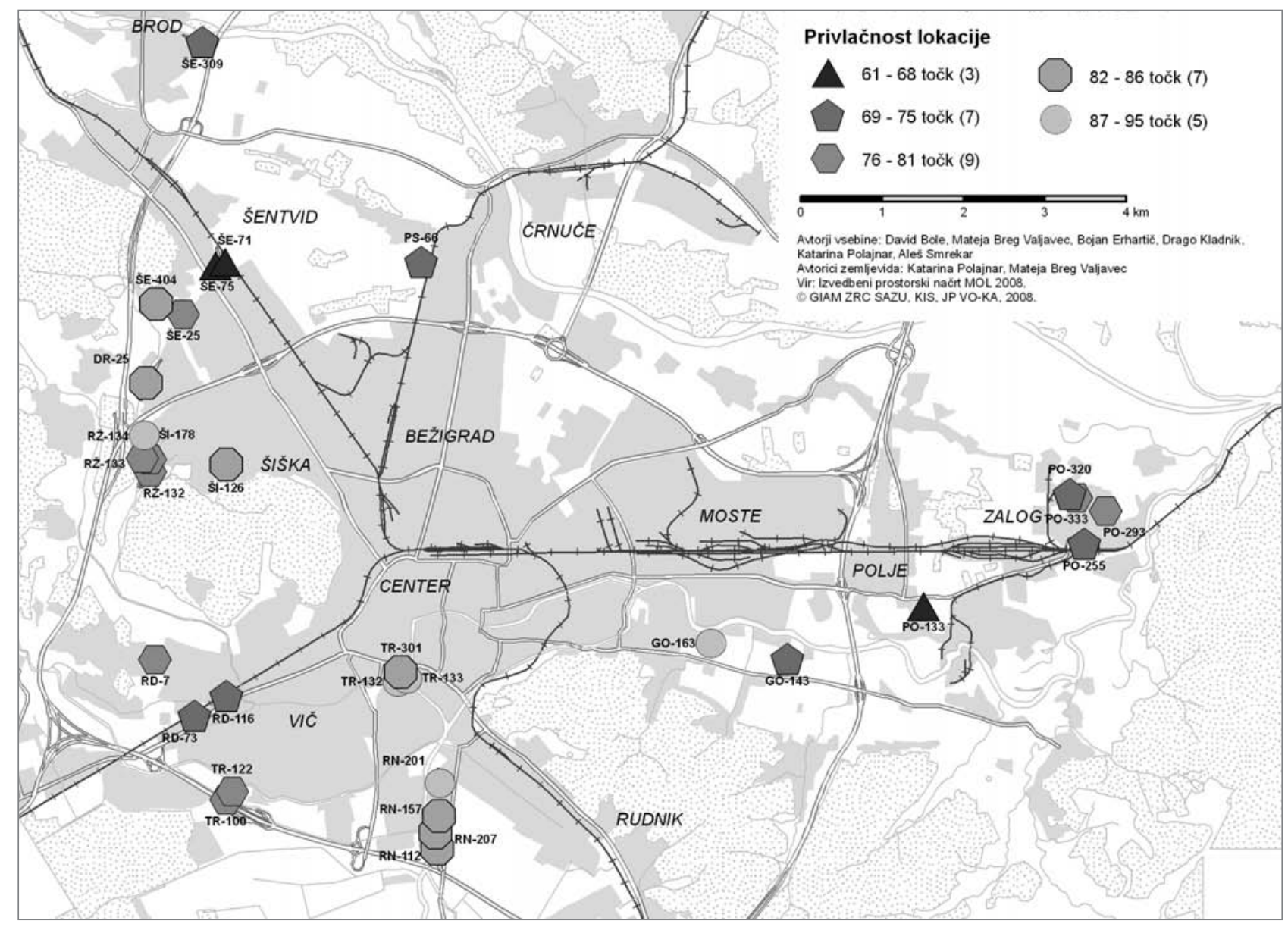

Slika 8: Točkovanje vrtičkarskih območij, predvidenih v osnutku IPN MOL, glede na merila privlačnosti (vir: Vrščaj idr., 2008). 
Lastniško sestavo vrtičkarskih območij v osnutku IPN smo ugotavljali s pomočjo digitalnega katastrskega načrta MOL. Lastništvo tamkajšnjih parcel smo razvrstili v štiri temeljne skupine:

- parcele v izključni lasti MOL oziroma z njo tesno povezanih ustanov (Stanovanjski sklad MOL, »stare « občine, na primer Ljubljana Center in podobno),

- parcele v izključni lasti Republike Slovenije oziroma določene državne ustanove ali nanjo tesno navezana podjetja (na primer ministrstvo za obrambo, Slovenske železnice, Slovenska odškodninska družba in podobno),

- parcele v prevladujoči lasti zasebnikov oziroma zasebnih podjetij,

- parcele v kategoriji »drugo«, katerih lastništvo je mešano (država/občina/zasebniki) oziroma spada v »javno dobro « ali celo ni znano.

Lastniška sestava na predvidenih vrtičkarskih območjih ni preveč ugodna (slika 9). Kar $72 \%$ parcel je v lasti zasebnikov, medtem ko jih je v lasti MOL le $16 \%$. Skupaj z lastništvom države je $\mathrm{v}$ javni lasti manj kot petina zemljišč, kar se lahko izkaže za precejšnjo oviro pri enotnem načrtovanju in opremljanju načrtovanih vrtičkarskih območij. Izraženo v prostor- ski enoti to pomeni, da je občina lastnica dobrih $87.000 \mathrm{~m}^{2}$, država $45.000 \mathrm{~m}^{2}$, zasebniki pa dobrih $402.000 \mathrm{~m}^{2}$ zemljišč na predvidenih vrtičkarskih območjih.

Kartografski prikaz lastniške sestave razkriva razlike med posameznimi območji. Še največji delež parcel v izključni lasti MOL je na predvidenih zaloških vrtičkih in na nekaterih viških vrtičkih, na kar 24 od 31 območij pa občinski delež zemljišč ne dosega niti četrtine od njihove celotne predvidene površine. Država ima izključno lastništvo le na enem izmed načrtovanih območij (Savlje), kjer je kot edini lastnik vpisano obrambno ministrstvo. Pomembnejši lastniški delež ima država le še na predvidenem vrtičkarskem območju ob Savi.

Na 23 od 31 vrtičkarskih območij iz osnutka IPN MOL je več kot polovica zemljǐ̌č v zasebni lasti. Izstopajo zlasti posamezniki (fizične osebe), v redkih primerih so večji lastniki tudi pravne osebe, med katerimi prevladujejo gradbena in nepremičninska podjetja. Tudi po površini največja vrtičkarska območja so prevladujoče $\mathrm{v}$ zasebni lasti - največje površine vrtičkov so predvidene na Livadi, kjer je lastniški delež občine in države manjši od petine. Tudi na obsežnejših predvidenih vrtičkarskih območjih v Šiški, Dravljah in Kosezah prevladujejo zasebni lastniki.

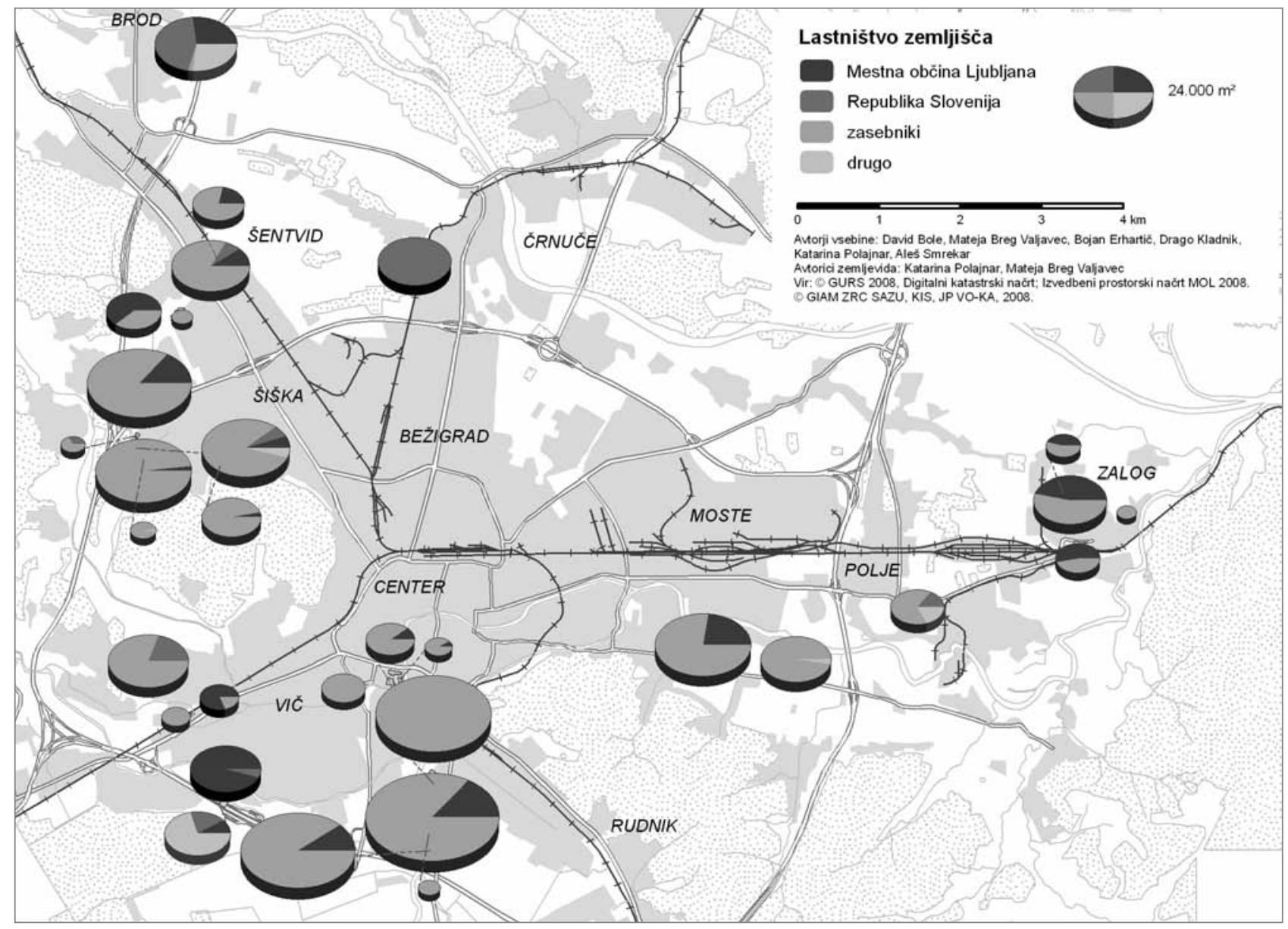

Slika 9: Lastniška sestava vrtičkarskih območij, predvidenih v osnutku IPN MOL (vir: Vrščaj idr., 2008). 
Lastniška sestava vrtičkarskih območij je torej potencialno problematična. MOL namreč obvladuje majhen delež zemljišč in ima zato dokaj omejene vzvode za enotnejše in skladnejše urejanje teh območij. Problematično, drago in zamudno zna biti že njihovo pridobivanje. Odkup več kot $400.000 \mathrm{~m}^{2}$ zasebnih površin je namreč velik finančni strošek, zato bodo lokalne oblasti na predvidenih vrtičkarskih območjih najbrž morale razmišljati tudi o vzpostavljanju zasebno-javnega partnerstva. Ob upoštevanju preteklih nesoglasij pa je gotovo nujno treba iskati konsenz med občino, lastniki zemljišč in vrtičkarji ter tudi intenzivnejše vključevanje laične in strokovne javnosti.

\section{Sklep}

Več kot tri četrtine $(77,8 \%)$ ljubljanskih vrtičkarjev načrtujejo, da se bodo z vrtičkarstvom ukvarjale še vnaprej, vsaj še v naslednjih petih letih. Takšna trdnost je glede na njihovo neugodno starostno sestavo nekoliko presenetljiva, vendar skriva v sebi trdno željo po nadaljevanju zanje življenjsko pomembne dejavnosti in ohranjanja posebnega življenjskega sloga. Le 2,6 \% jih je izjavilo, da nameravajo vrtiček obdelovati samo še leto ali manj (Vrščaj idr., 2008).

Med anketiranimi vrtičkarji jih je 44,3\% obstoječi vrtiček pripravljenih zamenjati za ustrezno opremljen vrtiček na (z vidika mesta) primernejši lokaciji, 47,0 \% pa jih tega ni pripravljenih storiti. Slaba desetina $(8,7 \%)$ je neopredeljena. Glede na starostno in izobrazbeno sestavo vrtičkarjev med posameznimi kategorijami vrtičkarjev ni opaznih razlik. Ob domnevi, da kakovost pridelane hrane na obstoječem vrtičku ne bi bila ustrezna, bi bili pripravljeni prevzeti vrtiček na drugi lokaciji dobri dve petini vprašanih vrtičkarjev (41,7\%), preostali pa so $s$ sedanjo lokacijo svojih vrtičkov povsem zadovoljni in ne bi pristali na menjavo niti pri poslabšani kakovosti pridelane hrane. Dobra desetina $(11,0 \%)$ o tem še nima izoblikovanega mnenja. Stopnja pripravljenosti preselitve vrtička je izrazito višja pri bolj izobraženih vrtičkarjih (Vrščaj idr., 2008).

Notranja diferenciacija pa je opazna med posameznimi vrtičkarskimi območji. Izrazita večina na zamenjavo pripravljenih vrtičkarjev je na območjih ob Hradeckega cesti pod Golovcem, Krakovski ulici v Krakovem, Gramozni poti na Fužinah in Ulici Jožeta Jame v Zgornji Šiški, več kot polovični delež pozitivnih odgovorov pa smo zabeležili tudi na območjih ob Aleševčevi ulici za Bežigradom, Litostrojski cesti v Šiški, Saveljski cesti v Savljah, Črnušnjici na Črnučah, Šmartinski in Letalǐ̌ki cesti v Mostah, Cesti Dolomitskega odreda na Brdu in ob Cesti dveh cesarjev na Viču. Na drugi strani so območja z močno prevlado vrtičkarjev, ki na tako zamenjavo niso pripravljeni. Izstopajo območja ob Vrtnarski cesti v Šentvidu, Kranjčevi ulici za Bežigradom, Agrokombinatski cesti v Zalogu, v Štepanjskem naselju, ob Cesti na Brdo, potoku Curnovcu v Rakovi Jelši, Cesti na Vrhovce in Hladnikovi cesti v Trnovem (Vrščaj idr., 2008).

Odpor proti preselitvi vrtičkov je pomembna okoliščina, ki jo je pri načrtovanju novih območij treba upoštevati. To pomeni, da je za preprečitev poglabljanja medsebojnega nezaupanja in nasprotovanja treba zagotoviti dogovorno odločanje, vključevanje zainteresirane javnosti ter vzpostavitev dialoga med občino in vrtičkarji. To prav tako lahko pomeni, da je nekatera obstoječa (sanirana) vrtičkarska območja morda smiselno ohraniti, seveda če ustrezajo vsem lokacijskim in drugim omejitvenim dejavnikom.

Dr. David Bole, univ. dipl. geogr., znanstveni sodelavec Geografski inštitut Antona Melika Znanstvenoraziskovalnega centra Slovenske akademije znanosti in umetnosti, Ljubljana, Slovenija E-pošta: david.bole@zrc-sazu.si

Mateja Breg Valjavec, univ. dipl. geogr., asistentka Geografski inštitut Antona Melika Znanstvenoraziskovalnega centra Slovenske akademije znanosti in umetnosti, Ljubljana, Slovenija E-pošta: mateja.breg@zrc-sazu.si

Bojan Erhartič, univ. dipl. geogr., asistent Geografski inštitut Antona Melika Znanstvenoraziskovalnega centra Slovenske akademije znanosti in umetnosti, Ljubljana, Slovenija E-pošta: bojaner@zrc-sazu.si

Dr. Drago Kladnik, prof. geogr. in zgod., višji znanstveni sodelavec Geografski inštitut Antona Melika Znanstvenoraziskovalnega centra Slovenske akademije znanosti in umetnosti, Ljubljana, Slovenija E-pošta: drago.kladnik@zrc-sazu.si

Katarina Polajnar, univ. dipl. geogr., asistentka Geografski inštitut Antona Melika Znanstvenoraziskovalnega centra Slovenske akademije znanosti in umetnosti, Ljubljana, Slovenija E-pošta: katarina.polajnar@zrc-sazu.si

Dr. Aleš Smrekar, univ. dipl. geogr. in univ. dipl. etn., znanstveni sodelavec

Geografski inštitut Antona Melika Znanstvenoraziskovalnega centra Slovenske akademije znanosti in umetnosti, Ljubljana, Slovenija E-pošta: ales.smrekar@zrc-sazu.si

\section{Zahvala}

Članek je rezultat raziskovalnega projekta Vrtičkarstvo v Mestni občini Ljubljana kot vir onesnaženosti v tleh, pridelani hrani in podzemni vodi, ki smo ga pripravili sodelavci G eografskega inštituta Antona Melika Znanstvenoraziskovalnega centra Slovenske akademije znanosti, Kmetijskega inštituta Slovenije (nosilna ustanova) in Javnega podjetja Vodovod - Kanalizacija, d. o. o. Za financiranje se zahvaljujemo Službi za razvojne projekte Mestne občine Ljubljana.

\section{Viri in literatura}

Christl, l., Gultz, P. A., Kretzschmar, R., in Schulin, R. (2004): Umgang mit bodenbelastungen in familiengärten der stadt Zürich. Institut für 
terrestrische Ökologie. Zürich, Institut für terrestrische Ökologie, ETH Zürich.

Doležal, M., Strojin Božič, Z., in Turk., M. (2005): Reševanje problematike vrtičkov na območju MOL. Poročilo št. 2. Ljubljana, Mestna občina Ljubljana.

Geodetska uprava Republike Slovenije (2005): Digitalni ortofoto 2005. Ljubljana.

Geodetska uprava Republike Slovenije (2008): Digitalni katastrski načrt 2008. Ljubljana.

Goriup, Z. (1984): Planiranje in urejanje območij malih vrtov (vrtičkov) v Ljubljani. Elaborat. Ljubljana, Urbanistični inštitut Slovenije.

Gregorič, L., Hafner Petrovski, S., Maslo, G., Dežman Markič, T., Strojin, Z., in Doležal, M. (2004): Reševanje problematike vrtičkov na območju MOL. Poročilo št. 1. Ljubljana, Mestna občina Ljubljana.

Internet 1: http://www.mk.gov.si/si/splosno/cns/novica/browse/6/ article/2130/5395/?\&tx_ttnews\%5Byear\%5D=2007\&tx_ttnews\%5Bm onth\%5D=02\&cHash=c196405f08 (sneto 7. 4. 2009).

Internet 2: http://www.ljubljana.si/si/mol/mestni_svet/seje/78575/ detail.html (sneto 3. 3. 2009).

Mestna občina Ljubljana (2008): Izvedbeni prostorski načrt Mestne občine Ljubljana. Dostopno na: http://urbanizem.ljubljana.si/index. htm (sneto 18. 4. 2008).

Petkovšek, J. (2009): Potrebujemo zakon, ne le odlok. Delo, 51(24), 30. 1. 2009, str. 9.

Rebernik, D. (2000): Morfološka zgradba. V: Gabrovec, M., Orožen Adamič, M (ur.): Ljubljana - geografija mesta, str. 39-52. Ljubljana, Ljubljansko geografsko društvo, Založba ZRC.

Simoneti, M., Bevk, J., Pintar, M., Zupan, M., Gajšek, P., Golobič, M., Pleško, R., in Bevk, M. (1997): Usmeritve in pogoji za nadaljnji razvoj vrtičkarstva v Ljubljani. Poročilo o razvojno-raziskovalni nalogi. Ljubljana, Ljubljanski urbanistični zavod.

Simoneti, M. (2000): Narava $v$ mestu - med načrtovanim in spontanim. Dostopno na: http://www.dkas.si/?id=3,9,42 (sneto 17. 6. 2008).

Simoneti, M., Kranjc, U., Musek, A., Šorn, M., Vidic, L., in Dobnikar, T. (2007): Urejanje vrtičkarskih območij v Ljubljani. Strokovne podlage. Ljubljana, Ljubljanski urbanistični zavod.

Smrekar, A., in Kladnik, D. (2007): Zasebni vodnjaki in vrtine na območju Ljubljane. Ljubljana, Geografski inštitut Antona Melika ZRC SAZU.

Vastl, N. (2000): Vrtičkarstvo. Specialistična naloga. Ljubljana, Univerza v Ljubljani, Fakulteta za arhitekturo.

Vrščaj, B., Sušin, J., Simončič, A., Markelc, I., Glad, J., Palčič, T., Smrekar, A., Bole, D., Breg, M., Erhartič, B., Kladnik, D., Polajnar, K., Jamnik, B., Nartnik, M., in Auersperger, P. (2008): Vrtičkarstvo v Mestni občini Ljubljana kot vir onesnaženosti v tleh, pridelani hrani in podzemni vodi. Elaborat. Ljubljana, Kmetijski inštitut Slovenije, Geografski inštitut Antona Melika ZRC SAZU, Javno podjetje Vodovod - kanalizacija, d. o. o. 